Accepted Manuscript

\title{
Journal of the Geological Society
}

\section{The Eastern Khoy Metamorphic Complex of NW Iran: a Jurassic ophiolite or continuation of the Sanandaj-Sirjan Zone?}

\author{
Hadi Shafaii Moghadam, Fernando Corfu, Robert J Stern \& Ali Lotfibakhsh
}

DOI: https://doi.org/10.1144/jgs2018-081

Received 13 April 2018

Revised 15 December 2018

Accepted 18 December 2018

(C) 2018 The Author(s). Published by The Geological Society of London. All rights reserved. For permissions: http://www.geolsoc.org.uk/permissions. Publishing disclaimer:

www.geolsoc.org.uk/pub_ethics

To cite this article, please follow the guidance at http://www.geolsoc.org.uk/onlinefirst\#cit_journal

\section{Manuscript version: Accepted Manuscript}

This is a PDF of an unedited manuscript that has been accepted for publication. The manuscript will undergo copyediting, typesetting and correction before it is published in its final form. Please note that during the production process errors may be discovered which could affect the content, and all legal disclaimers that apply to the journal pertain.

Although reasonable efforts have been made to obtain all necessary permissions from third parties to include their copyrighted content within this article, their full citation and copyright line may not be present in this Accepted Manuscript version. Before using any content from this article, please refer to the Version of Record once published for full citation and copyright details, as permissions may be required. 


\title{
The Eastern Khoy Metamorphic Complex of NW Iran: a Jurassic ophiolite or continuation of the Sanandaj-Sirjan Zone?
}

\author{
Hadi Shafaii Moghadam ${ }^{1,2 *}$, Fernando Corfu ${ }^{3}$, Robert J Stern ${ }^{4}$ \& Ali Lotfibakhsh ${ }^{2}$ \\ ${ }^{1}$ School of Earth Sciences, Damghan University, Damghan 36716-41167, Iran \\ ${ }^{2}$ Department of Geology, Faculty of Sciences, University of Mohaghegh Ardabili, Ardabil \\ 56199-13131, Iran \\ ${ }^{3}$ Department of Geosciences, University of Oslo, Blindern, N-0316 Oslo, Norway \\ ${ }^{4}$ Geosciences Department, University of Texas at Dallas, Richardson, TX 75083-0688, USA \\ *Corresponding author: (e-mail: hadishafaii@ yahoo.com)
}

\begin{abstract}
The Khoy complex in NW Iran has been widely regarded to consist of both Jurassic and Cretaceous ophiolites but, while the western Late Cretaceous ophiolite is unequivocal, the nature of the eastern Jurassic body has been unclear. Field observations show that the presumed eastern meta-ophiolite has no similarities to an ophiolite sequence. Here, we report geological and zircon-rutile-titanite $\mathrm{U}-\mathrm{Pb}$ data for rocks from the presumed Jurassic ophiolite obtained to verify whether these are real ophiolitic units and to understand their relations either to the Late Cretaceous Zagros-Bitlis ophiolites in W Iran-S Anatolia or to the SevanAkera (N Armenia) and Izmir-Ankara (S Pontides) complexes. The new U-Pb ages show that the "presumed" ophiolite is in fact a collage of Ediacaran to Cambrian $(\sim 606-517 \mathrm{Ma})$ and Jurassic ( 160 Ma) meta-igneous rocks, similar to ages obtained for igneous rocks of the Sanandaj-Sirjan Zone, which has been interpreted as a Jurassic continental rift. The Jurassic igneous rocks contain abundant Ediacaran, Ordovician-Silurian and Carboniferous-Permian inherited zircons, further suggesting involvement of pre-existing continental crust. Our results indicate that Jurassic continental rifting provided a lithospheric weakness along which a new subduction zone formed in Late Cretaceous times.
\end{abstract}

Keywords: Khoy ophiolite, U-Pb ages, Tethys, Zagros-Bitlis suture zone, NW Iran. 
Ophiolites are fragments of oceanic lithosphere tectonically emplaced onto continents by plate tectonic processes and are of particular interest for reconstructing ancient plate boundaries. The internal architecture of ophiolites provides analogues for the oceanic lithosphere (e.g., Dilek \& Furnes, 2011, Dilek \& Furnes, 2014). Ophiolites are distinctive assemblages of ultramafic, mafic and felsic igneous rocks, commonly associated with pelagic sediments, that have long been recognized as important components of Neoproterozoic and younger orogenic belts (Metcalf \& Shervais, 2008). Ophiolite geochemical signatures provide key constraints on the geodynamic setting in which they formed, whereas their ages constrain when oceanic realms existed (Dilek \& Furnes, 2011). Nearly all ophiolites have undergone metamorphism and deformation on the seafloor. Ophiolite metamorphism can also be related to tectonic emplacement. Reconstructing the original architecture of metamorphosed, deformed ophiolites is challenging but essential for establishing whether or not an assemblage of mafic and ultramafic metamorphic rocks is a true ophiolite or formed in a different tectonic environment.

Supra-subduction zone-type (SSZ) ophiolites are abundant in the eastern Mediterranean region and include both Jurassic and Late Cretaceous examples. Jurassic ophiolites ( 185-170 Ma) of Anatolia are exposed along two suture zones: the intra-Pontide suture in the northwest separating Eurasia from the Sakarya block in the central Pontides; and the Izmir-AnkaraErzincan suture zone (IAESZ) to the south of the Pontides, which separates the Sakarya block from the Anatolide-Tauride belt (Colakoglu et al., 2012, Dilek \& Furnes, 2011, Goncuoglu et al., 2007, Maffione et al., 2017, Sarifakioglu et al., 2014, Sarıfakığlu et al., 2017) (Fig. 1). The Jurassic Kure ophiolite also occurs in the central Pontides and is an example of an ensialic back-arc basin (Alparsalan and Dilek, 2018). These Turkish Jurassic ophiolites may link up with Jurassic ophiolites further west in Greece and the Balkans. Furthermore, the north Armenia Jurassic ophiolites (with ${ }^{40} \mathrm{Ar}^{39} \mathrm{Ar}$ ages of $~ 165 \mathrm{Ma}$ ), which are common 
along the Sevan-Akera suture zone (Fig. 1), may connect to the northeast Anatolian Jurassic ophiolites (Galoyan et al., 2009). Jurassic ophiolites are also present in south Iran, in the Makran accretionary complex (McCall, 1997, McCall, 2002), which may connect to the Masirah Jurassic ophiolite of Oman. It seems that Jurassic ophiolites are absent from Central Iran.

The IAESZ includes Late Cretaceous SSZ-type ophiolites, distributed from Izmir in western Anatolia, through Ankara, to Erzincan in NE Anatolia (Sarıfakığlu et al., 2017) (Fig. 1). The Late Cretaceous ( 100-90 Ma) ophiolites are abundant along the $>3000 \mathrm{~km}$ southwest margin of Eurasia from Troodos (Cyprus) through Turkey and western Iran to Oman. These ophiolites are scattered in the southern parts of the Anatolide-Tauride belt and in Iran along the Bitlis-Zagros suture zone (Dilek \& Thy, 2009, Moghadam \& Stern, 2015) (Fig. 1). The ophiolites in northwestern Iran and eastern Iraq are all Late Cretaceous (Fig. 1 (Moghadam \& Stern, 2015)) but the Khoy ophiolite in NW Iran has been considered a possible exception, with the suggestion of an old, poly-metamorphosed ophiolite and a younger unmetamorphosed ophiolite. The presumed older ophiolite lies in the east and yields Jurassic K-Ar ages (both from whole rocks and amphibole separate analyses), whereas the younger ophiolite in the west has Late Cretaceous K-Ar and paleontological ages (KhalatbariJafari et al., 2003). The presumed Jurassic ophiolite is metamorphosed, and it has been thought to have formed in an accretionary prism during subduction of the Khoy oceanic crust beneath central Iran (Khalatbari-Jafari et al., 2003). It contains metamorphosed gabbros (now found as mafic gneisses), fractionated intrusions (felsic gneisses), lavas (greenschists) and accompanying sediments (phyllites and schists). However, field observations show that the presumed (eastern) meta-ophiolitic unit has no similarities to an ophiolite (distinct assemblages of ultramafic, mafic and felsic igneous rocks and overlying pelagic sediments). Moreover, there is no evidence of a mature arc east of the Khoy ophiolites, as would be 
expected if subduction had occurred during Jurassic to Cretaceous time. These observations, and the scarcity of Jurassic ophiolites in Iran, call the interpretation of a Jurassic eastern Khoy ophiolite into question. We need to test this interpretation in order to better understand the relations between the NW Iran ophiolite and N Armenia-NE Anatolia Jurassic oceanic basins (Rolland et al., 2009). The precise age and source of these presumed Jurassic rocks are also important for reconstructing the paleogeography and geodynamic setting of NW Iran during the Mesozoic. The relationship in space and time between the presumed Jurassic and Cretaceous magmatism is unclear. In this paper, we contribute to answering these questions by reporting zircon $\mathrm{U}-\mathrm{Pb}$ thermal ionization mass spectrometry ages and use these results to better understand the age and the origin of these rocks.

\section{Regional geology of W-NW Iran}

Here, we briefly outline different tectono-magmatic elements of W-NW Iran to better understand the relationship of the Khoy ophiolites and associated metamorphic rocks to other tectono-magmatic components of the Zagros orogenic belt of Iran. The Zagros orogenic belt extends from eastern Turkey through northern Iraq and along SW Iran to the Strait of Hormuz and into northern Oman. It is an active orogen, presently accommodating $\sim 22 \mathrm{~mm} \mathrm{yr}^{-1}$ of convergence between Arabia and Eurasia (Reilinger et al., 2006). In contrast to the Alps and Tibet, this orogenic system is in a "soft" collisional phase and convergence with Arabia has not yet obliterated the structure of the convergent margin. The Zagros orogenic belt in Iran consists of five tectonic zones, from undeformed trench fill (in the SW) to the Neoproterozoic crust of central Iran, including the (1) the Zagros fold-and-thrust belt; (2) Outer Belt (OB) Zagros ophiolites and associated Paleogene forearc basin; (3) the Sanandaj-Sirjan Zone (SaSZ); (4) Inner Belt (IB) Zagros ophiolites; and (5) the Urumieh-Dokhtar Magmatic Belt, which is built on Neoproterozoic crust of central Iran (Fig. 2). 


\section{The Zagros fold-thrust belt}

This belt is the externally deformed part of the Zagros orogenic belt (Alavi, 2004, Alavi, 2007). It extends for nearly $2000 \mathrm{~km}$ from southeastern Turkey through northern Syria and northeastern Iraq to western and southern Iran ( $\underline{\text { Alavi, 1994 }})$ and records the shortening and off-scraping of thick sediments from the northern margin of the Arabian platform, essentially representing an accretionary prism for the Iranian convergent margin (Farhoudi \& Karig, 1977).

\section{Zagros Outer Belt Ophiolites}

The Zagros Outer Belt (OB) ophiolites include the Kamyaran-Kermanshah ophiolites in the NW and Neyriz ophiolites in the SE (Fig. 2). OB ophiolites in the Kamyaran-Kermanshah region are emplaced on a thick Permian-Triassic sequence of pelagic limestones (Bisotun limestones), radiolarites and geochemically-enriched lavas that are similar to the Triassic ( $c a$ $230 \mathrm{Ma}$ ) alkaline magmatism of the Hawasina Nappes in Oman (Chauvet et al., 2011). The Permo-Triassic sequence was related to Gondwana rifting and opening of the Neotethys. The region behaved like a passive margin (marginal basin) during the Mesozoic until initiation of Late Cretaceous subduction and ophiolite formation (Wrobel-Daveau et al., 2010). The Late Cretaceous Kermanshah ophiolite includes mantle peridotites, flaser gabbros, coarse-grained gabbros, minor plagiogranites and lavas. Gabbroic dikes within the mantle section of the Kermanshah ophiolites show zircon U-Pb ages of $97 \mathrm{Ma}$ (Ao et al., 2015). The ophiolite is either covered or injected by Cenozoic volcano-sedimentary rocks, basaltic to andesitic rocks and granites.

The Neyriz region exposes three imbricated sheets, from bottom (SW) to top (NE): the Pichukan series, mélange unit and ophiolite ( $\underline{\text { Ricou, 1968) }}$. The Pichakun series consists of Upper Triassic to Middle Cretaceous pelagic limestones. Ophiolitic slices tectonically overlie the mélange unit and both ophiolite and mélange are thrust over the carbonates (Sarvak 
Formation; (Alavi, 1994)). The Neyriz ophiolite is composed of mantle and crustal units covered by Upper Cretaceous (Cenomanian-Turonian to lower Santonian) pelagic sediments. ${ }^{40} \mathrm{Ar} /{ }^{39} \mathrm{Ar}$ ages from crustal plagiogranites are $92.07 \pm 1.69$ and $93.19 \pm 2.48 \mathrm{Ma}$ (Babaie et al., 2006), whereas zircon $\mathrm{U}-\mathrm{Pb}$ results from plagiogranites and gabbros show ages of $100.1 \pm$ 2.3 and 93.4 $\pm 1.3 \mathrm{Ma}$, respectively (Monsef et al., 2018).

\section{Zagros Inner Belt Ophiolites}

Zagros Inner Belt (IB) ophiolites include, from NW to the SE, the Nain, Dehshir and Baft ophiolites (Fig. 2). Lithologically, the IB ophiolites are similar to each other and to OB ophiolites. Moderately depleted harzburgites with minor plagioclase lherzolite, gabbroic lenses and diabasic-gabbroic-plagiogranitic dikes make the mantle sequence of IB ophiolites whereas crustal units include minor gabbros and felsic intrusions, volcanic rocks, and overlying Globotruncana-bearing Upper Cretaceous (Coniacian-Maastrichtian) pelagic sediments. A fragmented sheeted dike complex also accompanies some of these ophiolites. Zircon U-Pb data on Nain plagiogranites show ages of $102.8 \pm 0.3$ and $101.2 \pm 0.2 \mathrm{Ma}$, whereas Dehshir plagiogranites show U-Pb ages of $100.9 \pm 0.2$ to $99 \pm 1.1$ Ma (Moghadam et al., 2013). The Baft ophiolite contains zircons with an age of 103.2 $\pm 2.4 \mathrm{Ma}$ (Moghadam \& Stern, 2015).

\section{Paleogene mélange-like oceanic tracts}

Protracted extension, which affected the Iranian plateau during the Paleogene, produced numerous arc-related extensional basins in the upper plate of the Neotethyan subduction zone. Some of these basins, like those in the Zagros near the Iraq-Iran border, rifted sufficiently to form new oceanic lithosphere. These continent-fringing basins were filled by magmatic rocks and with detritus derived from the Urumieh-Dokhtar Magmatic Belt. These basins were accreted to the edge of the continent during contractional phases of subduction. Traces of these basins are preserved in a region >220 km long, from Kermanshah, Iran to Hasanbag, 
Iraq (Fig. 2). Eocene mafic rocks and extensional basins are also abundant along the BitlisZagros suture zone in SE Turkey, where their genesis is ascribed to Neotethys subduction, slab detachment, extension and melting of a sub-continental lithospheric mantle (Dilek et al., 2010).

\section{Sanandaj-Sirjan Zone}

The SaSZ extends as a NW-SE-trending belt ( $1500 \mathrm{~km}$ long and $\sim 150-200 \mathrm{~km}$ wide) across southern Iran and consists of Phanerozoic magmatic, metamorphic and sedimentary rocks. This zone lies between the OB and IB ophiolites (Fig. 2). The SaSZ is mainly composed of Jurassic phyllites and Cretaceous metavolcanic rocks which have experienced a moderate, mostly greenschist facies, metamorphic overprint. The SaSZ is generally considered to represent the active Andean-like continental margin of the Zagros orogen that formed as a consequence of Neotethys subduction in the Early to Middle Jurassic (e.g., (Berberian \&

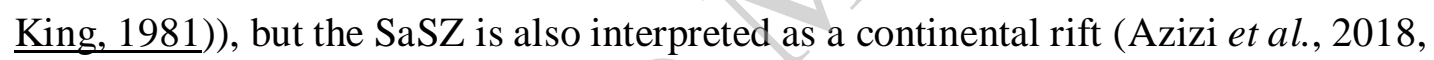
Hunziker et al., 2015). SaSZ plutonic rocks show zircon U-Pb age peaks at 185-160 Ma and 157-149 Ma (e.g., (Hassanzadeh \& Wernicke, 2016a, Mahmoudi et al., 2011, Shahbazi et al., 2010). Felsic igneous rocks are more abundant than mafic rocks and the mafic precursors have usually plume-like geochemical signatures and their genesis is linked to rifting (Azizi et al., 2018). Seismic reflection profiles indicate a mid-Jurassic rifting event in N Arabia that started at $\sim 185 \mathrm{Ma}$, lasted for $\sim 10 \mathrm{Myr}$ and resulted in $\sim 250-450 \mathrm{~m}$ of tectonic subsidence, with a subsidence rate of $0.025-0.045 \mathrm{~mm} / \mathrm{yr}$ (Ali et al., 2017). The stratigraphic succession of the Zagros basin also indicates the presence of syn-sedimentary extensional faults, unconformities, and facies changes in the Early to Middle Jurassic (e.g., Tavani et al., 2018), which attests that rifting was predominant in N Arabia - Iran during the Jurassic. 


\section{Urumieh-Dokhtar Magmatic Belt}

The Urumieh-Dokhtar Magmatic Belt is a 50-80 km wide magmatic belt that trends NW-SE for $1000 \mathrm{~km}$ across most of Iran. It evolved for $100 \mathrm{Ma}$, beginning with the modern phase of subduction starting in Late Cretaceous time and continuing through Cenozoic time (Berberian \& King, 1981). The Urumieh-Dokhtar Magmatic Belt defines the magmatic front of the Iranian arc and includes a thick $(\sim 4 \mathrm{~km})$ pile of calc-alkaline, shoshonitic and younger adakitic rocks.

\section{Neoproterozoic crust of Iran}

The basement of Central Iran is characterized by remarkably homogeneous Late Neoproterozoic (Ediacaran-Early Cambrian) crust. This old basement contains gneissic and granitic rocks with minor volcanic rocks and metamorphosed sediments (paragneisses and schists). These rocks have a restricted range of radiometric ages (500-600 Ma) and a distinctive, nearly chondritic Hf isotopic signature (Moghadam et al., 2015a). Cadomian exposures are abundant in Iran; they are reported from western (Golpayegan), northwestern (Khoy, Takab), northeastern (Torud, Taknar) and central Iran (Saghand) (Fig. 2).

\section{Geological setting of the Khoy ophiolite and the Eastern Khoy metamorphic complex}

The Zagros Orogen along the Iran-Iraq-Turkey border is marked by ophiolite massifs, distributed along the Main Zagros Thrust (Fig. 2). These ophiolites define a belt from Harsin to Kermanshah along the Iran-Iraq border (Fig. 2), continuing north to the Khoy-Maku ophiolites in NW Iran.

The Khoy-Maku ophiolite was first described by Hassanipak \& Ghazi (2000) who suggested that it formed as a Cretaceous back-arc basin northeast of the Zagros suture zone, including the Neyriz-Kermanshah-Iraqi ophiolites within the Iranian Ediacaran basement (Moghadam \& 
Stern, 2015). There are three main units in the Khoy region (Fig. 2), from NE to SW: (1) the continental margin of the Central Iranian block represented by slates and shales of the Ediacaran Kahar Formation; (2) an eastern metamorphic complex which is the suspected Jurassic meta-ophiolite; and (3) the unmetamorphosed Late Cretaceous Khoy ophiolite (Khalatbari-Jafari et al., 2003).

The eastern Khoy metamorphic unit (Khalatbari-Jafari et al., 2003) consists of micaschist, amphibolite and greenschist metavolcanics with MORB to SSZ geochemical affinities in close spatial association with gneiss and metagranite (Fig. 3). These rocks show variable amphibole and mica K-Ar ages, ranging from Early Jurassic (197-181 Ma), Middle Jurassic (160-155 Ma) and Early Cretaceous (121-102 Ma) to Late Cretaceous (81-69 Ma). Compared to the eastern Khoy metamorphic unit, the younger, unmetamorphosed Khoy ophiolite complex is similar to an ideal ophiolite, with distinct assemblages of ultramafic, mafic and felsic igneous rocks and overlying pelagic sediments. This ophiolite is composed of mantle peridotite, gabbros, diabasic dikes and a thick sequence (>2000 m) of phyric and aphyric pillowed and massive basalts (Fig. 3). Pelagic sediments cover and are interlayered with the basalts. Plagioclase from two isotropic gabbros and one diabasic dike within the ophiolitic gabbro yields K-Ar ages of 101-65 Ma (Khalatbari-Jafari et al., 2003). Stratigraphic and structural data indicate the Khoy ophiolite was thrust over Campanian olistostromes, and this was concomitant with intense erosion of the ophiolite (Hässig et al., 2017).

\section{Samples}

We collected six samples for $\mathrm{U}-\mathrm{Pb}$ zircon dating: an augen orthogneiss (1 sample), a finegrained granitic gneiss (1 sample), a meta-granitic dike within the gneissic amphibolites (1 sample), meta-granites (2 samples) and a flaser gabbro (1 sample) (Fig. 2). These samples come from SE and NW parts of the eastern metamorphic complex, where gneissic 
amphibolites, ortho- and paragneissic rocks along with both pelitic and mafic-schists are abundant (Figs. 4A-B). Metagranites to meta-granodiorites were injected into this sequence as dikes, sills or large stocks (1-2 km in diameter) (Figs. 4C-D). Highly deformed amphibolebearing gabbros (flaser gabbros) are exposed in the SE part of the region (Fig. 3). Flaser gabbros have normal to faulted contacts with gneissic rocks and greenschists to the NW of Parchi (Fig. 3), and also occur as small lenses within the psammitic gneissic rocks. The mineralogy and texture of the flaser gabbros differ from other rocks; these gabbros are highly deformed, but their deformation history and metamorphic grade are similar to other metamorphic rocks from the eastern Khoy metamorphic complex. Orthogneisses have a granodioritic composition and contain deformed plagioclase with rare orthoclase. Quartz mostly occurs as deformed fine-grained ribbons but large quartz porphyroclasts $(>2 \mathrm{~mm})$ are also present. Elongated biotite and amphibole are the ferromagnesian minerals in these rocks. Allanite, zircon and apatite are minor components. Granitic gneisses contain more quartz and orthoclase compared to the granodioritic gneisses, which are fine-grained and less deformed. Metagranites and granitic dikes have medium to coarse-grained quartz (1-2 mm) and orthoclase (2-4 $\mathrm{mm})$ phenocrysts. Biotite and plagioclase are minor components. Flaser (mylonitic) gabbros contain green to brown amphibole and large plagioclase porphyroclasts (3$5 \mathrm{~mm})$. Quartz, clinopyroxene and rutile occur as minor minerals. These rocks are highly deformed and are characterized by coarse-grained protomylonitic texture.

\section{Methods}

The samples were crushed and pulverized, and zircon separated using a Wilfley table, sieving, magnetic and heavy liquids. After selection under an optical microscope, zircon was subjected to chemical abrasion (Mattinson, 2005) whereas titanite and rutile were not abraded. The selected (zircon, rutile and titanite) grains were then spiked with a ${ }^{202} \mathrm{~Pb}^{205} \mathrm{~Pb}^{235} \mathrm{U}$ tracer, 
followed by dissolution, chemical separation of $\mathrm{Pb}$ and $\mathrm{U}$, and mass spectrometry, after the procedure detailed in (Krogh, 1973) with modifications described in (Corfu, 2004). The Pb measurements were done in part by static multi-collection on Faraday cups and for smaller ion beams dynamically with an ion counting secondary electron multiplier. The obtained data were corrected with fractionation factors determined from the ${ }^{205} \mathrm{~Pb} /{ }^{202} \mathrm{~Pb}$ ratio of the tracer (around $0.1 \% / \mathrm{amu}$ for $\mathrm{Pb}$ ) and $0.12 \% / \mathrm{amu}$ for $\mathrm{U}$, subtracting blanks of $0.1 \mathrm{pg} \mathrm{U}$, and $2 \mathrm{pg} \mathrm{Pb}$ or less when the total common $\mathrm{Pb}$ was below that level. The remaining initial $\mathrm{Pb}$ was corrected using compositions calculated with the model of Stacey \& Kramers (1975) except for the flaser gabbro where we measured $\mathrm{Pb}$ in hornblende. Plotting and regressions were done with the Isoplot software package (Ludwig, 2009). The decay constants are those of Jaffey et al., (1971).

\section{U-Pb geochronology results}

All the samples revealed complex data patterns reflecting the presence of more than one generation of zircon and/or variable amounts of $\mathrm{Pb}$ loss. CL images show most zircon have oscillatory zoning and inherited cores are abundant. No zircon with metamorphic, unzoned rims has been detected (Fig. 5).

The augen-orthogneiss sample KY15-11 contains mostly short prismatic euhedral to anhedral grains. Analyses of different types of grains (Table 1) are discordant and scattered. The data indicate a Late Neoproterozoic or Cambrian origin of the gneiss, but the details of the evolution are uncertain. The data can be delimited between two lines projected from about 159 Ma to 517-606 Ma (Fig. 6), which approximates the time of events that shaped the rocks. Meta-granites and meta-granitic dikes within the gneissic amphibolites and granitic gneisses all contain zircon populations dominated by short prismatic grains and rare elongated crystals, generally euhedral. Some grains have visible cores. The results demonstrate that most of the 
tested grains are inherited, even though the analyses were done on grains or pieces of grains representing thin prisms and tips, which normally have a lower probability of inheritance. Few analyzed zircons are juvenile and match the age of coexisting titanite. In sample KY15-9 (meta-granitic dike), titanite indicates an age of $159.1 \pm 0.9$ Ma (Fig. 6), which matches the age of a zircon tip giving $160.0 \pm 0.7 \mathrm{Ma}$ and is considered the best estimate for crystallization of the granite. In sample KY15-8 (granitic gneiss) one zircon and two titanite analyses combine to give an age of $158.3 \pm 2.4 \mathrm{Ma}$ (Fig. 6). In sample KY15-3 (meta-granite) all the zircon analyses are variously discordant, the youngest indicating $160.3 \pm 0.6 \mathrm{Ma}$ (Fig. 6). The zircon data plot on two different discordia lines defining identical lower intercept ages of $157.9 \pm 1.0$ and $157.9 \pm 2.5 \mathrm{Ma}$ whereas two analyses of titanite yield $155.6 \pm 1.1 \mathrm{Ma}$ (Fig. 6). A third analysis of titanite, which was somewhat more turbid than the others, is younger suggesting an isotopic disturbance of titanite. The lower intercept age of $157.9 \pm 2.5 \mathrm{Ma}$ overlaps various age constraints for this sample and is therefore considered the best estimate for the crystallization age of the granite. In sample KY15-4 (meta-granite) two zircon and two titanite analyses overlap indicating a crystallization age of 159.7 $0.5 \mathrm{Ma}$ (Fig. 6). Inheritance patterns point to different ages for the xenocrystic zircons. In sample KY15-9 the data scatter between two lines projecting to 655 and $510 \mathrm{Ma}$ (Fig. 6), which resembles the pattern observed in the gneiss, suggesting a provenance or contamination of the magmas from basement of that age. In sample KY15-8 all the data fit on one line, indicating provenance from a unique source with an age of $589 \pm 8$ Ma (Fig. 6). In sample KY15-3 two of the zircon analyses point to a source at $2047 \pm 5 \mathrm{Ma}$ while four others indicate a different source at 625 $\pm 12 \mathrm{Ma}$, and one grain suggests a provenance from ca. 450 Ma rocks (Fig. 6). Finally, sample KY15-4 has a very distinct inheritance pattern, with 4 zircons indicating a Silurian age of 436 \pm 7 Ma while two other grains are Permian at $282 \pm 11$ Ma (Fig. 6). 
A sample of the flaser gabbro did not yield any zircon, but contains some rutile, retrogressed partly to titanite (inset in Fig. 7B). Both rutile and titanite contain very small amounts of U (14 ppm, Table 2), but while rutile has almost no initial common $\mathrm{Pb}$ the titanite incorporated almost $10 \mathrm{ppm}$ common $\mathrm{Pb}$. The composition of initial $\mathrm{Pb}$ was measured in coexisting hornblende and used to construct $\mathrm{U}-\mathrm{Pb}$ isochrons (Fig. 7A), and also to correct the U-Pb data for the concordia plot.

Due to the small amount of radiogenic $\mathrm{Pb}$ in the rutiles, the $\mathrm{U}-\mathrm{Pb}$ analyses are not very precise. As shown in the concordia plot in Fig. $7 \mathrm{C}$, the rutile grains yield ${ }^{206} \mathrm{~Pb} /{ }^{238} \mathrm{U}$ ages of 144 to $133 \mathrm{Ma}$ and imprecise and unreliable ${ }^{207} \mathrm{~Pb} /{ }^{235} \mathrm{U}$ ages. In a ${ }^{238} \mathrm{U} /{ }^{204} \mathrm{~Pb} v{ }^{206} \mathrm{~Pb} /{ }^{204} \mathrm{~Pb}$ isochron diagram, three clean rutile analyses yield an age of $145 \pm 24 \mathrm{Ma}$ whereas the hornblende, titanite and mixed rutile + titanite isochron yield a more precise age of $147.8 \pm$ 0.9 Ma. A similar age, but very imprecise, is also indicated by the ${ }^{235} \mathrm{U} /{ }^{204} \mathrm{~Pb} v s^{207} \mathrm{~Pb} /{ }^{204} \mathrm{~Pb}$ isochron (Fig. 7B). Interestingly, the rutile isochron has to a lower ${ }^{206} \mathrm{~Pb} /{ }^{204} \mathrm{~Pb}$ initial ratio than titanite and hornblende, indicating an external source of $\mathrm{Pb}$ during alteration.

These new U-Pb data indicate that the gabbro formed in the Jurassic. In detail, the age of the rutile is likely younger than time of gabbro crystallization. In fact, the titanite appears to be older than rutile, even though it clearly formed by canibalizing rutile, and hence it must be younger. This is not an uncommon observation given that $\mathrm{U} / \mathrm{Pb}$ in rutile is more easily reset than in titanite (e.g. (Gasser et al., 2015)).

\section{Discussion}

\section{No Jurassic meta-ophiolite}

New zircon and titanite $\mathrm{U}-\mathrm{Pb}$ ages from the eastern Khoy metamorphic complex show that the augen orthogneiss formed in Ediacaran or Early Cambrian time, whereas the meta-granites represent Jurassic intrusions crystallized at 159.1 $\pm 0.9 \mathrm{Ma}, 158.3 \pm 2.4 \mathrm{Ma}, 157.9 \pm 2.5 \mathrm{Ma}$, 


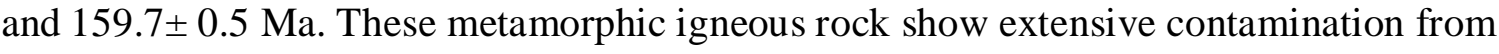
older crust with a variety of ages ranging from Ediacaran to Early Cambrian, but also with Late Ordovician to Silurian and Carboniferous-Permian components, and with a $2047 \mathrm{Ma}$ contribution, heretofore unknown from the crust of Iran but typical of the Eburnean crust of West Gondwana.

These results help explain the variable K-Ar ages (Early Jurassic to Late Cretaceous) reported by Khalatbari-Jafari et al., (2003). Zircon-rutile-titanite U-Pb ages are more precise and show two ages of magmatism: Ediacaran and Jurassic. The Jurassic ages obtained here agree with U-Pb zircon ages of 159 to $154 \mathrm{Ma}$, presented by Lechmann et al., (2018) for the Khoy area (Fig. 1). The rock associations of the eastern metamorphic complex (metagranites, gneisses, amphibolites and schists) do not look like an ophiolite sequence and indeed the new $\mathrm{U}-\mathrm{Pb}$ data confirm that some rocks have Ediacaran ages and those with Jurassic crystallization age s contain abundant inherited zircons, which is inconsistent with formation in an oceanic environment.

These new U-Pb ages for the Khoy metamorphic rocks are important for understanding the ancient plate tectonic events and plate boundary reconstructions during the JurassicCretaceous. They do not support the idea of a Jurassic ophiolite at Khoy nor an oceanic linkage between the Late Cretaceous ophiolites of NW Iran and Jurassic ophiolites of N Armenia (Sevan-Akera) or those of NE Anatolia (intra-Pontide and Izmir-Ankara). The latter ophiolites are believed to be slices of Middle Jurassic oceanic domains, called the Northern Neotethys Suture, which was obducted over the northern edge of the south Armenian and Tauride-Anatolide blocks (Hässig et al., 2017).

\section{Late Neoproterozoic-Early Cambrian crust and Jurassic magmatism}

Late Neoproterozoic-Early Cambrian (Cadomian) rocks are abundant in NW Iran, occurring in an area of $\sim 8000 \mathrm{~km}^{2}$, from S Urumieh to N Khoy (Fig. 2) and are linked to the Cadomian 
rocks of northeast, south and central Iran (Moghadam et al., 2017a). The Ediacaran rocks of N Urumieh (Fig. 1) yield zircon U-Pb ages of 571 $4.5 \mathrm{Ma}$ (Moghadam et al., 2015b), whereas the $\mathrm{S}$ Urumieh gabbros and granitic gneisses show $\mathrm{U}-\mathrm{Pb}$ ages of $544 \pm 1.5$ and $567 \pm 2.3 \mathrm{Ma}$ respectively (Moghadam et al., 2017a). The occurrence of Ediacaran rocks in Iran and Turkey is suggested to be linked to a long-lived magmatism (600-500 Ma) during the subduction of the Prototethys beneath northern Gondwana (Moghadam et al., 2017b). Late OrdovicianSilurian inherited zircons might have been fed from Ordovician-Silurian sedimentary rocks, which are common in NW Iran (e.g., Ranjbar Moghadam et al., 2018). The source of Permian inherited zircons is enigmatic, but there are several small Carboniferous A-type intrusions, alkaline gabbros and trondhjemitic sills in NW Iran - especially N of Urumieh - with ages of $317 \pm 1.9$ to $322 \pm 2.9 \mathrm{Ma}$ (Fig. 2) (Moghadam et al., 2015b).

Jurassic-Early Cretaceous igneous rocks are rare in Iran except in the SaSZ. The SaSZ is $\sim 100-150 \mathrm{~km}$ wide and $\sim 1500$ long and is elongated parallel to the Main Zagros Thrust (Mohajjel \& Fergusson, 2014). This zone makes up the metamorphic core of the Zagros Orogen and contains an extensive Mesozoic record of magmatism and metamorphism, although Ediacaran rocks are also common. Arc-type magmatism comprising voluminous calc-alkaline intrusive and extrusive rocks is the most distinctive component of the SaSZ, with magmatism that is as old as $187 \mathrm{Ma}$, with a pronounced peak at $170 \mathrm{Ma}$ in the southeast (Hassanzadeh \& Wernicke, 2016b) and youngs northwest to 150 Ma around Qorveh (Azizi et al., 2018, Mahmoudi et al., 2011).

Our new U-Pb ages indicate that the Khoy metamorphic rocks may be Jurassic SaSZ intrusions, which previously were thought to outcrop near Qorveh and southward (Fig. 2). Younger intrusions comprise leucogranites and gabbros with zircon $\mathrm{U}-\mathrm{Pb}$ ages of $144 \pm 2 \mathrm{Ma}$ (Azizi et al., 2011). Between Khoy and Qorveh, both older (Cadomian) and younger intrusions of the SaSZ are exposed, e.g., $\mathrm{N}$ to $\mathrm{S}$ Urumieh rocks with zircon $\mathrm{U}-\mathrm{Pb}$ ages of $571 \pm$ 
4.5 Ma (Moghadam et al., 2015b) and S Urumieh Late Cretaceous granites (K-Ar ages of 100-82 Ma; (Ghalamghash et al., 2009)). Our U-Pb ages are similar to those obtained for SaSZ igneous rocks and further implies that this zone can be traced as far north as Khoy, which agrees with the proposed northward continuation of the SaSZ suggested by Hassanzadeh \& Wernicke, (2016b).

Nearly all Jurassic SaSZ igneous rocks contain inherited zircons with variable ages, which are similar to inherited zircons found in our samples (Yang et al., 2018, Zhang et al., 2018a). Inherited Late Neoproterozoic zircons are most abundant, because these rocks dominate the crust of Iran and Anatolia (see Moghadam et al., 2017b). Moreover, Hf isotope data also confirm the recycling of crustal materials (supplier of the inherited zircons) during the genesis of Jurassic SaSZ igneous rocks (Chiu et al., 2017, Zhang et al., 2018b).

\section{A back-arc basin model for the formation of the Late Cretaceous Khoy ophiolite}

Our new ages support a back-arc basin model for the Late Cretaceous Khoy ophiolite, which is situated well northeast of the Zagros fore-arc ophiolites (Fig. 8). This back-arc oceanic realm was separated from the Zagros fore-arc by $\sim 100 \mathrm{~km}$ wide tract of Cadomian rocks, although this study confirms that Cadomian rocks also occur in the eastern parts of the Late Cretaceous Khoy ophiolite, in the continental crust of central Iran.

Both OB and IB ophiolites have comparable zircon $\mathrm{U}-\mathrm{Pb}$ ages and identical lithological associations. Slight variations in age are expected for subduction initiation-related oceanic

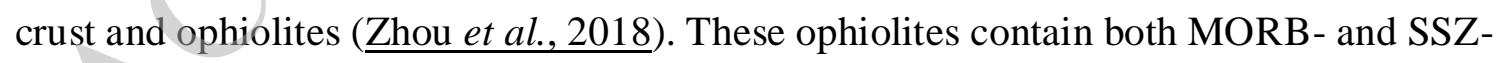
related igneous rocks which is normal in all fore-arc oceanic lithosphere and resulting ophiolites (Metcalf \& Shervais, 2008; Saccani et al., 2018). Detailed geochemical and isotopic signatures of both OB and IB mantle and crustal rocks show that both ophiolites are intact slices of forearc crust, generated at the southern margin of Eurasia during Late Cretaceous subduction initiation. We infer that Late Cretaceous subduction initiation began at 
104-98 Ma, as determined by zircon U-Pb dating of the Zagros fore-arc ophiolites (Moghadam et al., 2013, Moghadam \& Stern, 2015). Late Cretaceous subduction initiation changed plate trajectories; as a result the subsidence of Mesozoic Neotethys lithosphere commenced along a transform margin adjacent to the buoyant lithosphere of Eurasia, producing Zagros forearc ophiolites (Moghadam \& Stern, 2011, Moghadam et al., 2010). Foundering of Neotethys oceanic lithosphere induced extension on the southern margin of Eurasia during the Late Cretaceous, producing back-arc basins, tilting of crustal blocks, uplift and intense erosion of the Iranian plateau (Verdel et al., 2007).

There are several back-arc basins in Iran including the Late Cretaceous ophiolites in the NE Iran, the Caspian Sea in the N and Khoy in the NW, all of which were linked to subduction initiation-related hyperextension within the Iranian plateau. All these back-arc basins are surrounded by Cadomian rocks, and therefore, are classified as an ensialic back-arc basin. Subduction initiation is suggested to be a trigger for the formation of all Late Cretaceous Neotethyan ophiolites from Cyprus, the Mediterranean to Oman (e.g., (Dilek \& Thy, 2009, Pearce \& Robinson, 2010).

\section{Conclusions}

Results from our studies of the Khoy ophiolites from NW Iran based on new U-Pb analyses of zircon, rutile and titanite lead to the following conclusions: (1) The rocks in the suspected Khoy Jurassic ophiolites do not correspond to an ophiolite succession, i.e., distinct assemblages of ultramafic, mafic and felsic igneous rocks associated with siliceous pelagic sediments. (2) U-Pb zircon and titanite ages do not confirm the presence of a Jurassic ophiolite in NW Iran; there is only a Late Cretaceous oceanic remnant in this area. (3) U-Pb ages indicate that the "presumed" Jurassic ophiolite is actually a collage of Ediacaran continental crust overprinted by Jurassic igneous activity. (4) Recent investigations provide 
evidence of Jurassic oceanic slices in N Armenia (Sevan-Akera) and S Pontides (IzmirAnkara) that resulted from off-scraping of oceanic lithosphere in a south-dipping subduction zone under the northern margin of Armenian and Tauride-Anatolide blocks. Jurassic igneous activity in the Khoy region has no clear linkage with these complexes and instead is more likely to have formed as the NW extension of the Sanandaj-Sirjan Zone.

\section{Acknowledgments}

We are very grateful to Yildirim Dilek, Brian Wernicke and an anonymous reviewer for their constructive reviews of the manuscript. Editorial suggestions by Linda A. Kirstein are appreciated. All logistical supports come from Damghan University.

\section{References}

Alavi, M. (1994). Tectonics of the Zagros Orogenic Belt of Iran - New Data and Interpretations. Tectonophysics 229, 211-238.

Alavi, M. (2004). Regional stratigraphy of the Zagros fold-thrust belt of Iran and its proforeland evolution. American Journal of Science 304, 1-20.

Alavi, M. (2007). Structures of the Zagros fold-thrust belt in Iran. American Journal of Science 307, 1064-1095.

Ali, M. Y., Aidarbayev, S., Searle, M. P. \& Watts, A. B. (2017). Subsidence History and Seismic Stratigraphy of the Western Musandam Peninsula, Oman-United Arab Emirates Mountains. Tectonics 37, 154-181.

Alparslan, G., Dilek, Y. (2018). Seafloor spreading structure, geochronology, and tectonic evolution of the Kure ophiolite, Turkey: A Jurassic continental backarc basin oceanic lithosphere in southern Eurasia. Lithosphere 10, 14-34.

Ao, S., Xiao, W., Jafari, M. K., Talebian, M., Chen, L., Wan, B., Ji, W. \& Zhang, Z. (2015). U-Pb zircon ages, field geology and geochemistry of the Kermanshah ophiolite (Iran): From continental rifting at 79Ma to oceanic core complex at ca. 36Ma in the southern Neo-Tethys. Gondwana Research.

Azizi, H., Lucci, F., Stern, R. J., Hasannejad, S. \& Asahara, Y. (2018). The Late Jurassic Panjeh submarine volcano in the northern Sanandaj-Sirjan Zone, northwest Iran: Mantle plume or active margin? Lithos 308, 364-380 
Azizi, H., Tanaka, T., Asahara, Y., Chung, S. L. \& Zarrinkoub, M. H. (2011). Discrimination of the age and tectonic setting for magmatic rocks along the Zagros thrust zone, northwest Iran, using the zircon $\mathrm{U}-\mathrm{Pb}$ age and $\mathrm{Sr}-\mathrm{Nd}$ isotopes. Journal of Geodynamics 52, 304-320.

Babaie, H. A., Babaei, A., Ghazi, A. M. \& Arvin, M. (2006). Geochemical, Ar-40/Ar-39 age, and isotopic data for crustal rocks of the Neyriz ophiolite, Iran. Canadian Journal of Earth Sciences 43, 57-70.

Berberian, M. \& King, G. C. P. (1981). Towards a Paleogeography and Tectonic Evolution of Iran. Canadian Journal of Earth Sciences 18, 210-265.

Centeno-Garcia, E., Busby, C., Busby, M. \& Gehrels, G. (2011). Evolution of the Guerrero composite terrane along the Mexican margin, from extensional fringing arc to contractional continental arc. Geological Society of America Bulletin 123, 1776-1797.

Chauvet, F., Lapierre, H., Maury, R. C., Bosch, D., Basile, C., Cotten, J., Brunet, P. \& Campillo, S. (2011). Triassic alkaline magmatism of the Hawasina Nappes: Post-breakup melting of the Oman lithospheric mantle modified by the Permian Neotethyan Plume. Lithos 122, 122-136.

Chiu, H. Y., Chung, S. L., Zarrinkoub, M. H., Melkonyan, R., Pang, K. N., Lee, H. Y., Wang, K. L., Mohammadi, S. S. \& Khatib, M. M. (2017). Zircon Hf isotopic constraints on magmatic and tectonic evolution in Iran: Implications for crustal growth in the Tethyan orogenic belt. Journal of Asian Earth Sciences 145, 652-669.

Colakoglu, A. R., Sayit, K., Gunay, K. \& Goncuoglu, M. C. (2012). Geochemistry of mafic dykes from the Southeast Anatolian ophiolites, Turkey: Implications for an intra-oceanic arcbasin system. Lithos 132, 113-126.

Corfu, F. (2004). U-Pb age, setting and tectonic significance of the anorthosite-mangeritecharnockite-granite suite, Lofoten-Vesteralen, Norway. Journal of Petrology 45, 1799-1819.

Dercourt, J., Zonenshain, L. P., Ricou, L. E., Kazmin, V. G., Lepichon, X., Knipper, A. L., Grandjacquet, C., Sbortshikov, I. M., Geyssant, J., Lepvrier, C., Pechersky, D. H., Boulin, J., Sibuet, J. C., Savostin, L. A., Sorokhtin, O., Westphal, M., Bazhenov, M. L., Lauer, J. P. \& Bijuduval, B. (1986). Geological Evolution of the Tethys Belt from the Atlantic to the Pamirs since the Lias. Tectonophysics 123, 241-315.

Dilek, Y., Imamverdiyev, N., Altunkaynak, S. (2010). Geochemistry and tectonics of Cenozoic volcanism in the Lesser Caucasus (Azerbaijan) and the peri-Arabian region: collision-induced mantle dynamics and its magmatic fingerprint. International Geology Review 52, 536-578.

Dilek, Y. \& Furnes, H. (2011). Ophiolite genesis and global tectonics: Geochemical and tectonic fingerprinting of ancient oceanic lithosphere. Geological Society of America Bulletin 123, 387-411. 
Dilek, Y. \& Furnes, H. (2014). Ophiolites and Their Origins. Elements 10, 93-100.

Dilek, Y. \& Thy, P. (2009). Island arc tholeiite to boninitic melt evolution of the Cretaceous Kizildag (Turkey) ophiolite: Model for multi-stage early arc-forearc magmatism in Tethyan subduction factories. Lithos 113, 68-87.

Farhoudi, G. \& Karig, D. (1977). Makran of Iran and Pakistan as an active arc system. Geology 5, 664-668.

Galoyan, G., Rolland, Y., Sosson, M., Corsini, M., Billo, S., Verati, C. \& Melkonyan, R. (2009). Geology, geochemistry and (40)Ar/(39)Ar dating of Sevan ophiolites (Lesser Caucasus, Armenia): Evidence for Jurassic Back-arc opening and hot spot event between the South Armenian Block and Eurasia. Journal of Asian Earth Sciences 34, 135-153.

Gasser, D., Jerabek, P., Faber, C., Stunitz, H., Menegon, L., Corfu, F., Erambert, M. \& Whitehouse, M. J. (2015). Behaviour of geochronometers and timing of metamorphic reactions during deformation at lower crustal conditions: phase equilibrium modelling and U$\mathrm{Pb}$ dating of zircon, monazite, rutile and titanite from the Kalak Nappe Complex, northern Norway. Journal of Metamorphic Geology 33, 513-534.

Ghalamghash, J., Nedelec, A., Bellon, H., Abedini, M. V. \& Bouchez, J. L. (2009). The Urumieh plutonic complex (NW Iran): A record of the geodynamic evolution of the SanandajSirjan zone during Cretaceous times - Part I: Petrogenesis and K/Ar dating. Journal of Asian Earth Sciences 35, 401-415.

Goncuoglu, M. C., Capkinoglu, S., Gursu, S., Noble, P., Turhan, N., Tekin, U. K., Okuyucu, C. \& Goncuoglu, Y. (2007). The Mississippian in the Central and Eastern Taurides (Turkey): constraints on the tectonic setting of the Tauride-Anatolide Platform. Geologica Carpathica 58, 427-442.

Hassanipak, A. A. \& Ghazi, A. M. (2000). Petrology, geochemistry and tectonic setting of the Khoy ophiolite, northwest Iran: implications for Tethyan tectonics. Journal of Asian Earth Sciences 18, 109-121.

Hassanzadeh, J. \& Wernicke, B. P. (2016a). The Neotethyan Sanandaj-Sirjan zone of Iran as an archetype for passive margin-arc transitions. Tectonics 35, 586-621.

Hassanzadeh, J. \& Wernicke, B. P. (2016b). The Neotethyan Sanandaj - Sirjan zone of Iran as an archetype for passive margin - arc transitions. Tectonics 35, 586-621.

Hässig, M., Rolland, Y. \& Sosson, M. (2017). From seafloor spreading to obduction: Jurassic-Cretaceous evolution of the northern branch of the Neotethys in the Northeastern Anatolian and Lesser Caucasus regions. Geological society, London, special publications 428, 41-60. 
Hunziker, D., Burg, J. P., Bouilhol, P. \& von Quadt, A. (2015). Jurassic rifting at the Eurasian Tethys margin: Geochemical and geochronological constraints from granitoids of North Makran, southeastern Iran. Tectonics 34, 571-593.

Jaffey, A., Flynn, K., Glendenin, L., Bentley, W. t. \& Essling, A. (1971). Precision measurement of half-lives and specific activities of U 235 and U 238. Physical Review C 4, 1889.

Kazmin, V. G., Sbortshikov, I. M., Ricou, L. E., Zonenshain, L. P., Boulin, J. \& Knipper, A. L. (1986). Volcanic Belts as Markers of the Mesozoic-Cenozoic Active Margin of Eurasia. Tectonophysics 123, 123-152.

Khalatbari-Jafari, M., Juteau, T., Bellon, H. \& Emami, H. (2003). Discovery of two ophiolite complexes of different ages in the Khoy area (NW Iran). Comptes Rendus Geoscience 335, 917-929.

Krogh, T. (1973). A low-contamination method for hydrothermal decomposition of zircon and extraction of $\mathrm{U}$ and $\mathrm{Pb}$ for isotopic age determinations. Geochimica Et Cosmochimica Acta 37, 485-494.

Lechmann, A., Burg, J.-P., Ulmer, P., Mohammadi, A., Guillong, M. (2018). From Jurassic rifting to Cretaceous subduction in NW Iranian Azerbaijan: geochronological and geochemical signals from granitoids. Contributions to Mineralogy and Petrology 173, 101117.

Ludwig, K. R. (2009). Isoplot 4.1. A geochronological toolkit for Microsoft Excel. Berkeley Geochronology Center Special Publication, 76.

Maffione, M., Hinsbergen, D. J., Gelder, G. I., Goes, F. C. \& Morris, A. (2017). Kinematics of Late Cretaceous subduction initiation in the Neo - Tethys Ocean reconstructed from ophiolites of Turkey, Cyprus, and Syria. Journal of Geophysical Research: Solid Earth 122, 3953-3976.

Mahmoudi, S., Corfu, F., Masoudi, F., Mehrabi, B. \& Mohajjel, M. (2011). U-Pb dating and emplacement history of granitoid plutons in the northern Sanandaj-Sirjan Zone, Iran. Journal of Asian Earth Sciences 41, 238-249.

Mattinson, J. M. (2005). Zircon U-Pb chemical abrasion (“CA-TIMS”) method: combined annealing and multi-step partial dissolution analysis for improved precision and accuracy of zircon ages. Chemical Geology 220, 47-66.

McCall, G. J. H. (1997). The geotectonic history of the Makran and adjacent areas of southern Iran. Journal of Asian Earth Sciences 15, 517-531.

Mccall, G. J. H. (2002). A summary of the geology of the Iranian Makran. Tectonic and Climatic Evolution of the Arabian Sea Region 195, 147-204. 
Metcalf, R. V. \& Shervais, J. W. (2008). Suprasubduction-zone ophiolites: Is there really an ophiolite conundrum? Ophiolites, Arcs, and Batholiths: A Tribute to Cliff Hopson 438, 191222.

Moghadam, H. S., Corfu, F. \& Stern, R. J. (2013). U-Pb zircon ages of Late Cretaceous NainDehshir ophiolites, central Iran. Journal of the Geological Society 170, 175-184.

Moghadam, H. S., Griffin, W. L., Li, X. H., Santos, J. F., Karsli, O., Stern, R. J., Ghorbani, G., Gain, S., Murphy, R. \& O'Reilly, S. Y. (2017a). Crustal Evolution of NW Iran: Cadomian Arcs, Archean Fragments and the Cenozoic Magmatic Flare-Up. Journal of Petrology 58, 2143-2190.

Moghadam, H. S., Khademi, M., Hu, Z. C., Stern, R. J., Santos, J. F. \& Wu, Y. B. (2015a). Cadomian (Ediacaran-Cambrian) arc magmatism in the ChahJam-Biarjmand metamorphic complex (Iran): Magmatism along the northern active margin of Gondwana. Gondwana Research 27, 439-452.

Moghadam, H. S., Li, X.-H., Santos, J. F., Stern, R. J., Griffin, W. L., Ghorbani, G. \& Sarebani, N. (2017b). Neoproterozoic magmatic flare-up along the N. margin of Gondwana: The Taknar complex, NE Iran. Earth and Planetary Science Letters 474, 83-96.

Moghadam, H. S., Li, X. H., Ling, X. X., Stern, R. J., Santos, J. F., Meinhold, G., Ghorbani, G. \& Shahabi, S. (2015b). Petrogenesis and tectonic implications of Late Carboniferous Atype granites and gabbronorites in NW Iran: Geochronological and geochemical constraints. Lithos 212, 266-279.

Moghadam, H. S. \& Stern, R. J. (2011). Geodynamic evolution of Upper Cretaceous Zagros ophiolites: formation of oceanic lithosphere above a nascent subduction zone. Geological Magazine 148, 762-801.

Moghadam, H. S. \& Stern, R. J. (2015). Ophiolites of Iran: Keys to understanding the tectonic evolution of SW Asia: (II) Mesozoic ophiolites. Journal of Asian Earth Sciences 100, 31-59.

Moghadam, H. S., Stern, R. J. \& Rahgoshay, M. (2010). The Dehshir ophiolite (central Iran): Geochemical constraints on the origin and evolution of the Inner Zagros ophiolite belt. Geological Society of America Bulletin 122, 1516-1547.

Mohajjel, M. \& Fergusson, C. L. (2014). Jurassic to Cenozoic tectonics of the Zagros Orogen in northwestern Iran. International Geology Review 56, 263-287.

Monsef, I., Monsef, R., Mata, J., Zhang, Z., Pirouz, M., Rezaeian, M., Esmaeili, R. \& Xiao, W. (2018). Evidence for an early-MORB to fore-arc evolution within the Zagros suture zone: Constraints from zircon $\mathrm{U}-\mathrm{Pb}$ geochronology and geochemistry of the Neyriz ophiolite (South Iran). Gondwana Research.

Pearce, J. \& Robinson, P. (2010). The Troodos ophiolitic complex probably formed in a subduction initiation, slab edge setting. Gondwana Research 18, 60-81. 
Ranjbar Moghadam, F., Masoudi, F., Corfu, F. \& Homam, S.M. (2018). Ordovician mafic magmatism in an Ediacaran arc complex, Sibak, NE Iran: the eastern tip of the Rheic Ocean. Canadian Journal of Earth Sciences, in press, doi.org/10.1139/cjes-2018-0072.

Reilinger, R., McClusky, S., Vernant, P., Lawrence, S., Ergintav, S., Cakmak, R., Ozener, H., Kadirov, F., Guliev, I., Stepanyan, R., Nadariya, M., Hahubia, G., Mahmoud, S., Sakr, K., ArRajehi, A., Paradissis, D., Al-Aydrus, A., Prilepin, M., Guseva, T., Evren, E., Dmitrotsa, A., Filikov, S. V., Gomez, F., Al-Ghazzi, R. \& Karam, G. (2006). GPS constraints on continental deformation in the Africa-Arabia-Eurasia continental collision zone and implications for the dynamics of plate interactions. Journal of Geophysical Research 111.

Ricou, L. E. (1968). Formation of Important Radiolarite and Ophiolite Layers during Upper Cretaceous in Zagros Mountains (Iran). Comptes Rendus Hebdomadaires Des Seances De L Academie Des Sciences Serie D 267, 2272-\&.

Rolland, Y., Billo, S., Corsini, M., Sosson, M. \& Galoyan, G. (2009). Blueschists of the Amassia-Stepanavan Suture Zone (Armenia): linking Tethys subduction history from ETurkey to W-Iran. International Journal of Earth Sciences 98, 533-550.

Saccani, E., Dilek, Y., and Photiades, A. (2018). Time-progressive mantle-melt evolution and magma production in a Tethyan marginal sea: A case study of the Albanide-Hellenide ophiolites. Lithosphere 10, 35-53.

Sarifakioglu, E., Dilek, Y. \& Sevin, M. (2014). Jurassic-Paleogene intraoceanic magmatic evolution of the Ankara Melange, north-central Anatolia, Turkey. Solid Earth 5, 77-108.

Sarıfakığlu, E., Dilek, Y. \& Sevin, M. (2017). New synthesis of the Izmir-Ankara-Erzincan suture zone and the Ankara mélange in northern Anatolia based on new geochemical and geochronological constraints.

Shahbazi, H., Siebel, W., Pourmoafee, M., Ghorbani, M., Sepahi, A. A., Shang, C. K. \& Abedini, M. V. (2010). Geochemistry and U-Pb zircon geochronology of the Alvand plutonic complex in Sanandaj-Sirjan Zone (Iran): New evidence for Jurassic magmatism. Journal of Asian Earth Sciences 39, 668-683.

Stacey, J. S. \& Kramers, J. D. (1975). Approximation of Terrestrial Lead Isotope Evolution by a 2-Stage Model. Earth and Planetary Science Letters 26, 207-221.

Tavani, S., Parente, M., Vitale, S., Iannace, A., Corradetti, A., Bottini, C., Morsalnejad, D., Mazzoli, S. (2018). Early Jurassic rifting of the Arabian passive continental margin of the Neo-Tethys: Field evidence from the Lurestan region of the Zagros fold-and-thrust belt, Iran. Tectonics, in press, DOI: 10.1029/2018TC005192. 
complexes in the Saghand region of central Iran. Geological Society of America Bulletin 119, 961-977.

Wrobel-Daveau, J. C., Ringenbach, J. C., Tavakoli, S., Ruiz, G. M. H., Masse, P. \& de Lamotte, D. F. (2010). Evidence for mantle exhumation along the Arabian margin in the Zagros (Kermanshah area, Iran). Arabian Journal of Geosciences 3, 499-513.

Yang, T. N., Chen, J. L., Liang, M. J., Xin, D., Aghazadeh, M., Hou, Z. Q. \& Zhang, H. R. (2018). Two plutonic complexes of the Sanandaj-Sirjan magmatic-metamorphic belt record Jurassic to Early Cretaceous subduction of an old Neotethys beneath the Iran microplate. Gondwana Research 62, 246-268.

Zhang, H., Chen, J., Yang, T., Hou, Z. \& Aghazadeh, M. (2018a). Jurassic granitoids in the northwestern Sanandaj-Sirjan Zone: Evolving magmatism in response to the development of a Neo-Tethyan slab window. Gondwana Research 62, 269-286.

Zhang, Z., Xiao, W., Ji, W., Majidifard, M. R., Rezaeian, M., Talebian, M., Xiang, D., Chen, L., Wan, B., Ao, S. \& Esmaeili, R. (2018b). Geochemistry, zircon U-Pb and Hf isotope for granitoids, NW Sanandaj-Sirjan zone, Iran: Implications for Mesozoic-Cenozoic episodic magmatism during Neo-Tethyan lithospheric subduction. Gondwana Research 62, 227-245.

Zhou, X., Li, Z. H., Gerya, T. V., Stern, R. J., Xu, Z. Q. \& Zhang, J. J. (2018). Subduction initiation dynamics along a transform fault control trench curvature and ophiolite ages. Geology 46, 607-610. 


\section{Figure captions}

Figure 1. Simplified map showing the distribution of suture zones, major ophiolite complexes from the Tethyan realm in Turkey and Iran emphasizing the Zagros outer and inner belt ophiolites, Sanandaj-Sirjan zone, Walash-Naopurdan-Kamyaran Paleogene oceanic tracts and Late Neoproterozoic rocks (modified after Dilek et al., 2010 (his Fig. 1).).

Figure 2. Simplified geological map of Iran showing the Zagros inner and outer belt Late Cretaceous ophiolites, Sanandaj-Sirjan zone, Walash-Naopurdan-Kamyaran Paleogene oceanic tracts, the Urumieh-Dokhtar magmatic belt and Late Neoproterozoic rocks. Modified after Azizi et al., 2018

Figure 3. Geological map of the Khoy Late Cretaceous ophiolite and "presumed" Jurassic meta-ophiolite (modified after Khalatbari-Jafary et al., 2003 (Fig. 1C in his paper).). The location of samples for new U-Pb (this study), zircon U-Pb ages (Lechmann et al., 2018) and K-Ar (Khalatbari-Jafari et al., 2003) ages are shown.

Figure 4. Field photos of the eastern Khoy metamorphic complex. (A) paragneisses and interlayered amphibolites, (B), mafic (green-) schists, (C) meta-granitic dikes within the amphibolites and (D) a meta-granodioritic stock within the greenschists.

Figure 5. Cathodoluminescence images of typical zircons from the studied Khoy Jurassic samples.

Figure 6. Zircon-titanite stacked concordia diagrams displaying U-Pb data for the Khoy metaigneous rocks. Ellipses represent $2 \sigma$ errors.

Figure 7. U-Pb isochrons and concordia plot for rutile, titanite, and hornblende of flaser gabbro sample KY15-1.

Figure 8. Schematic model showing the opening and evolution of the Khoy back-arc basin in regard to the Zagros, Neotethyan Ocean (modified after (Dercourt et al., 1986, Kazmin et al., 1986). Abbreviations: $\mathrm{BSB}=$ Black Sea Basin, $\mathrm{GCB}=$ Great Caucasus Basin, $\mathrm{SCB}=$ South 
Caspian Basin, KB= Khoy Basin, KR= Kermanshah ophiolite, NY= Neyriz ophiolite, $\mathrm{OM}=$ Oman ophiolite.

\section{Table captions}

Table 1. U-Pb data from the Khoy "presumed" meta-ophiolite.

Table 2. $\mathrm{U}-\mathrm{Pb}$ and $\mathrm{Pb}-\mathrm{Pb}$ data for Khoy flaser gabbros. 
Downloaded from http://jgs.lyellcollection.org/ by guest on January 11, 2019

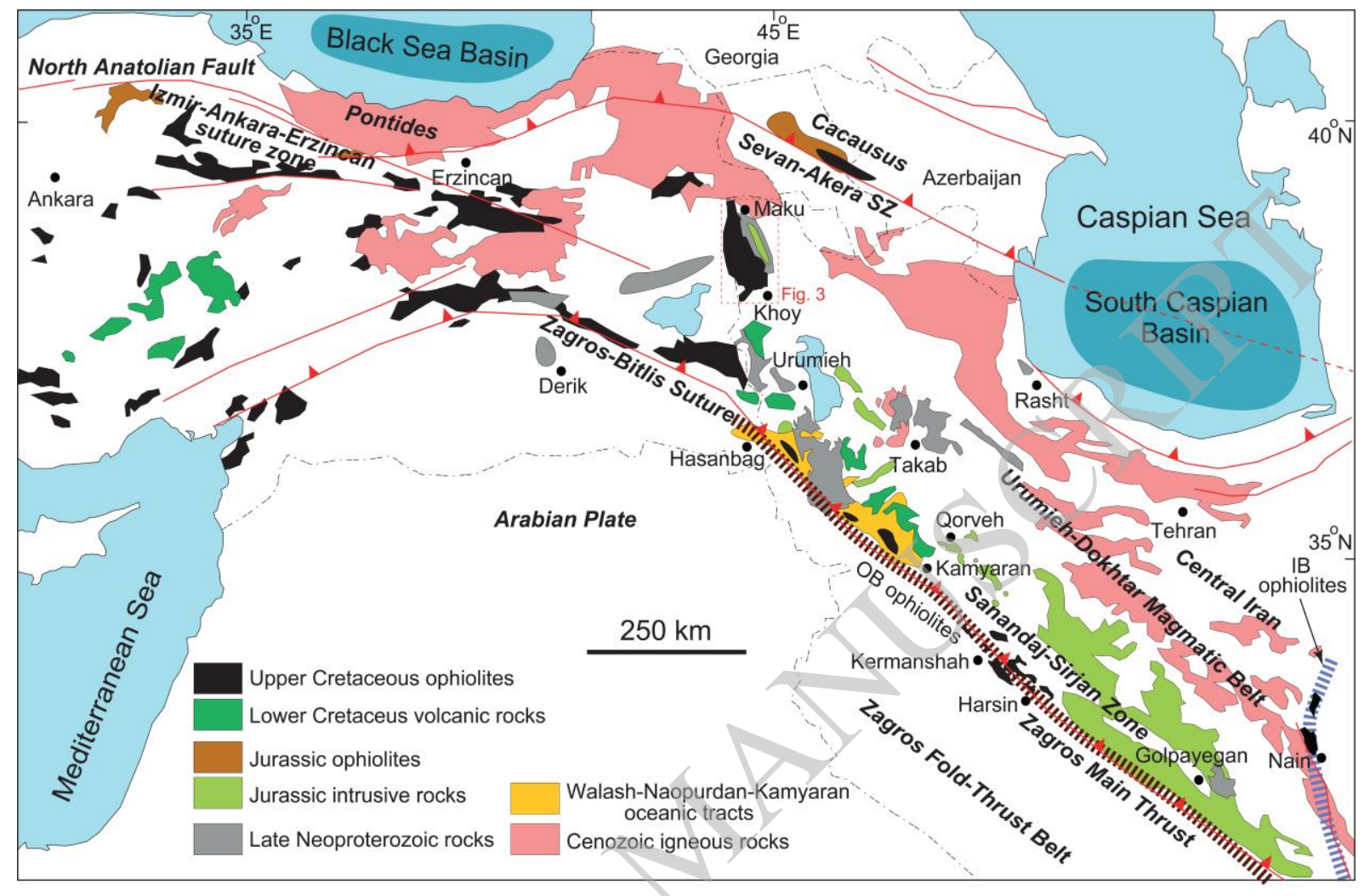




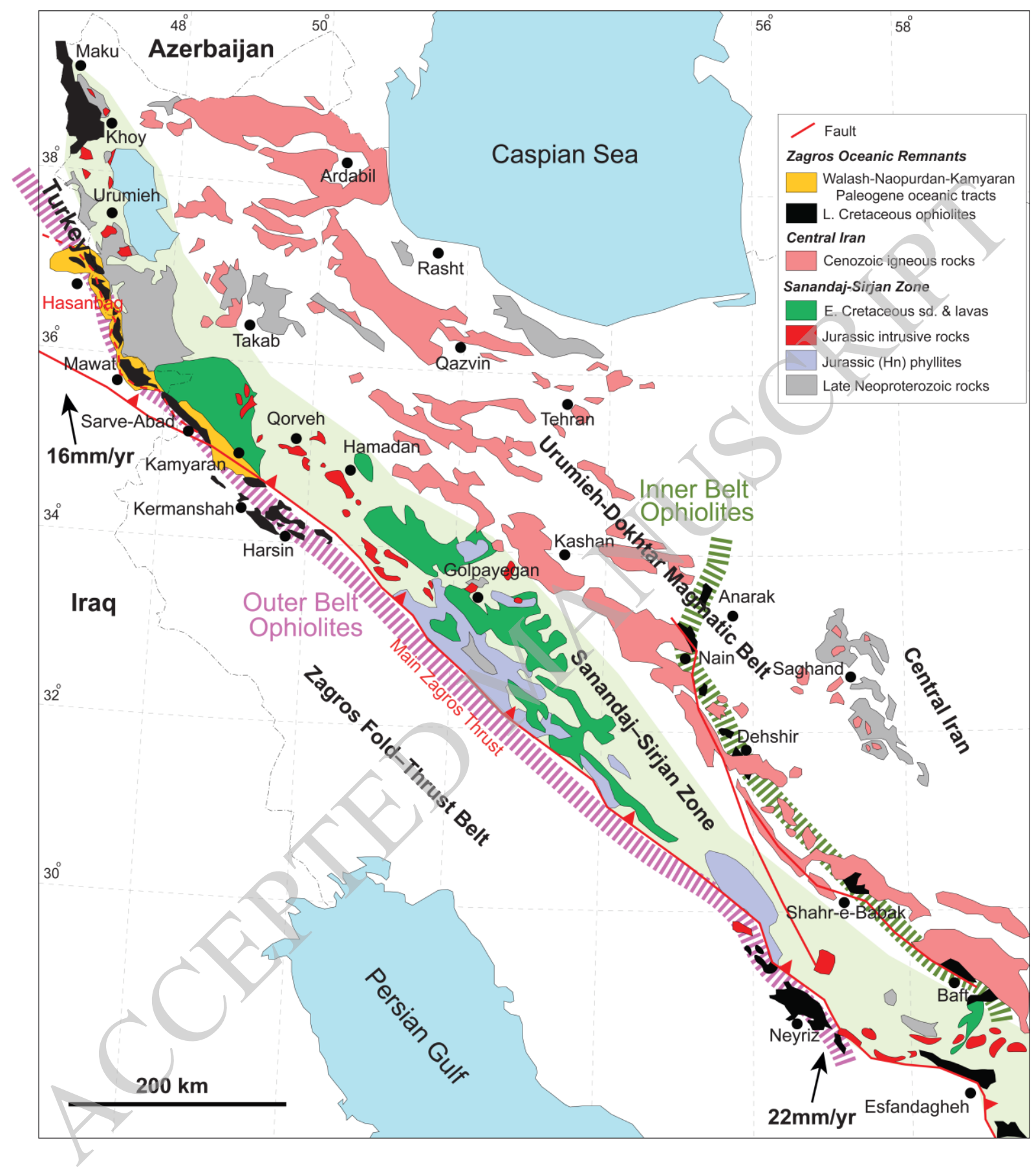




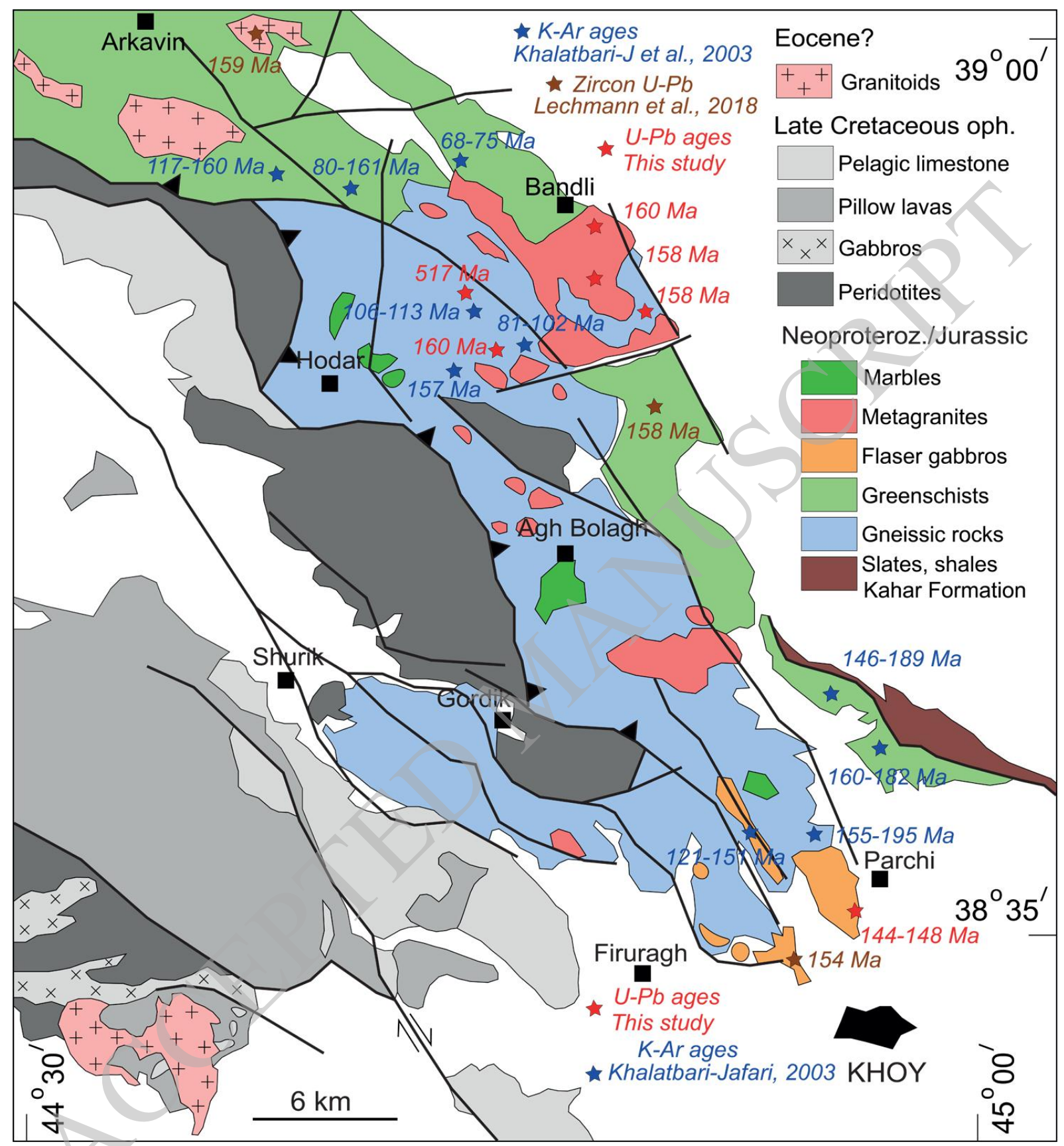



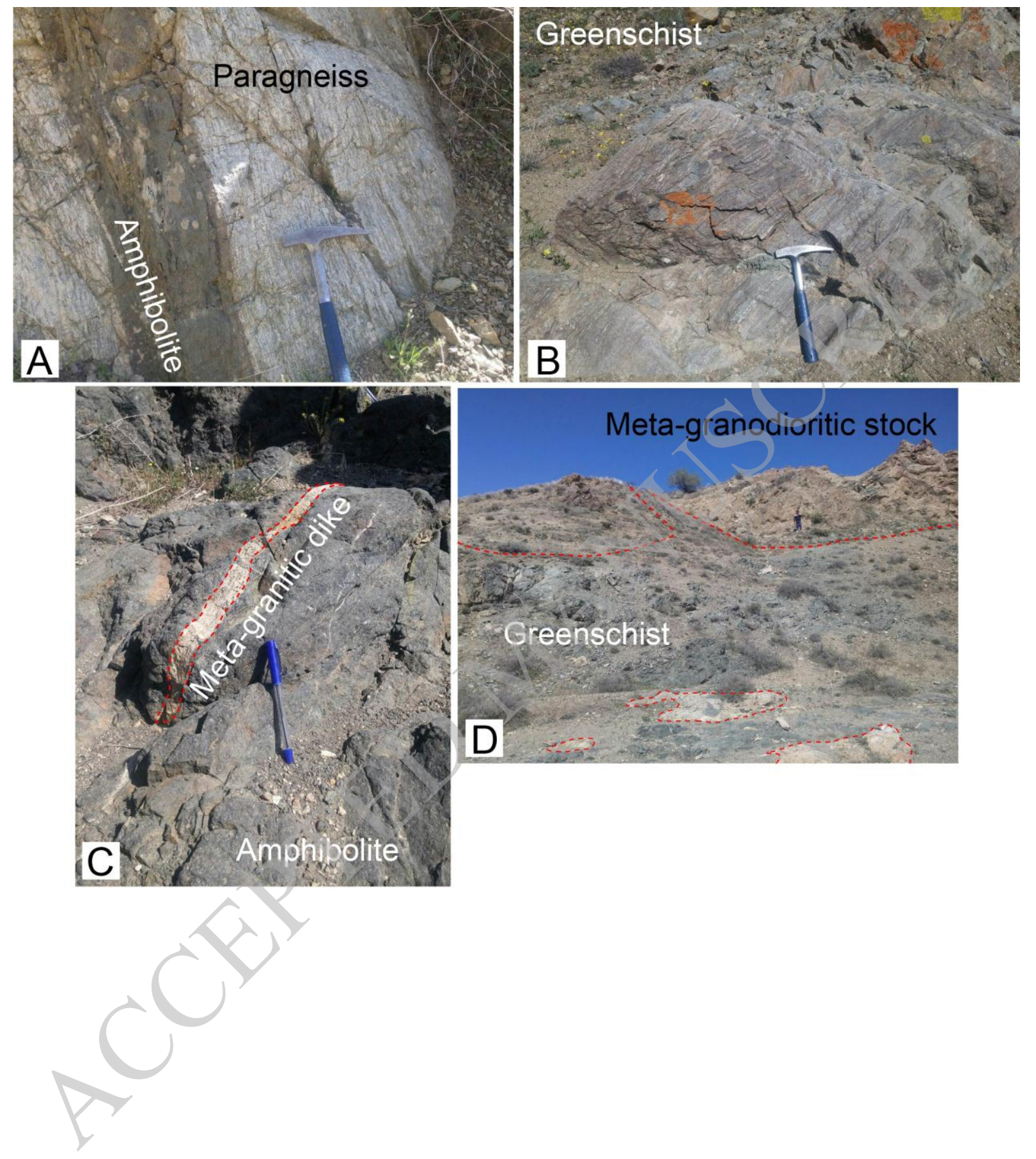


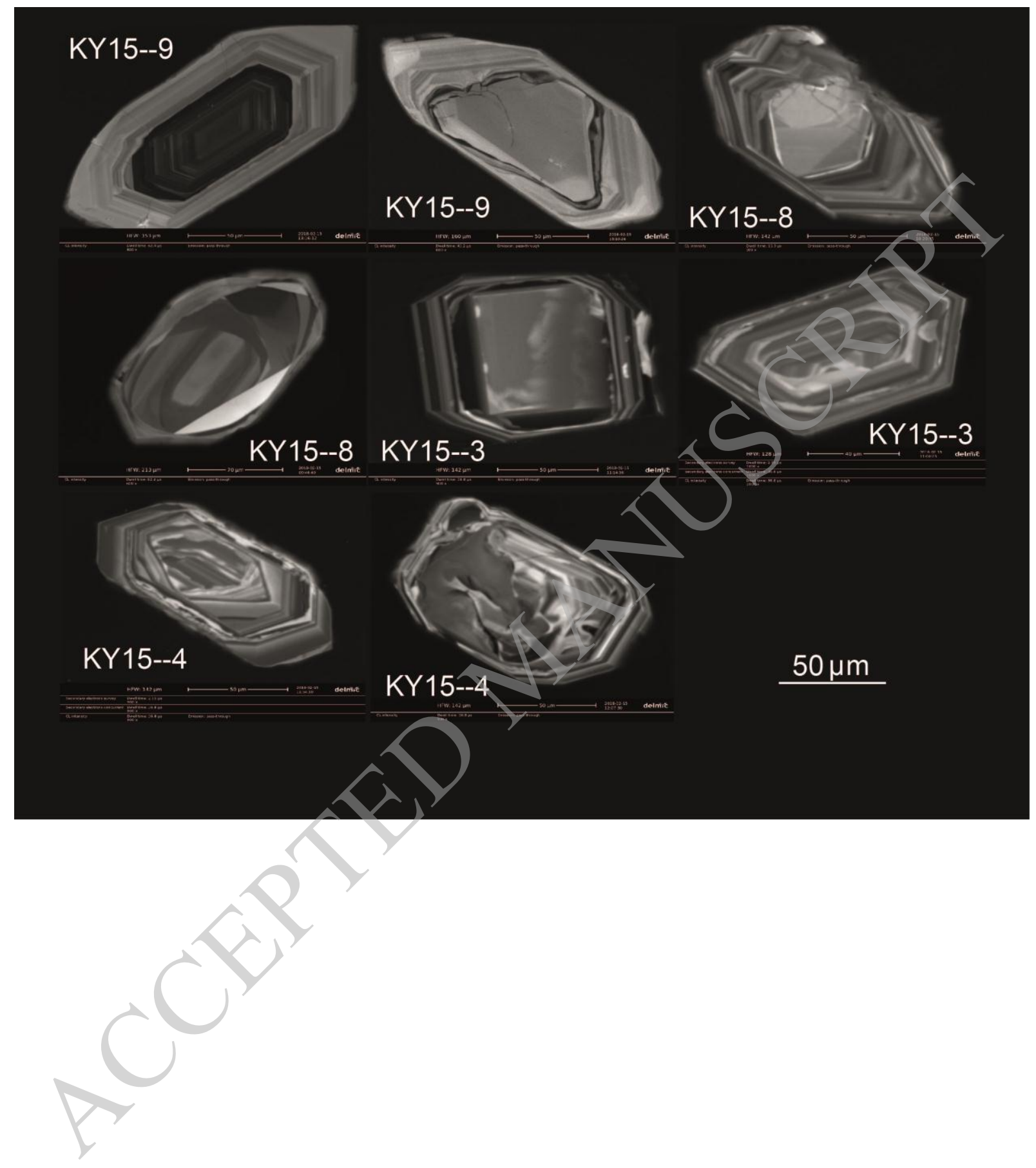


Downloaded from http://jgs.lyellcollection.org/ by guest on January 11, 2019
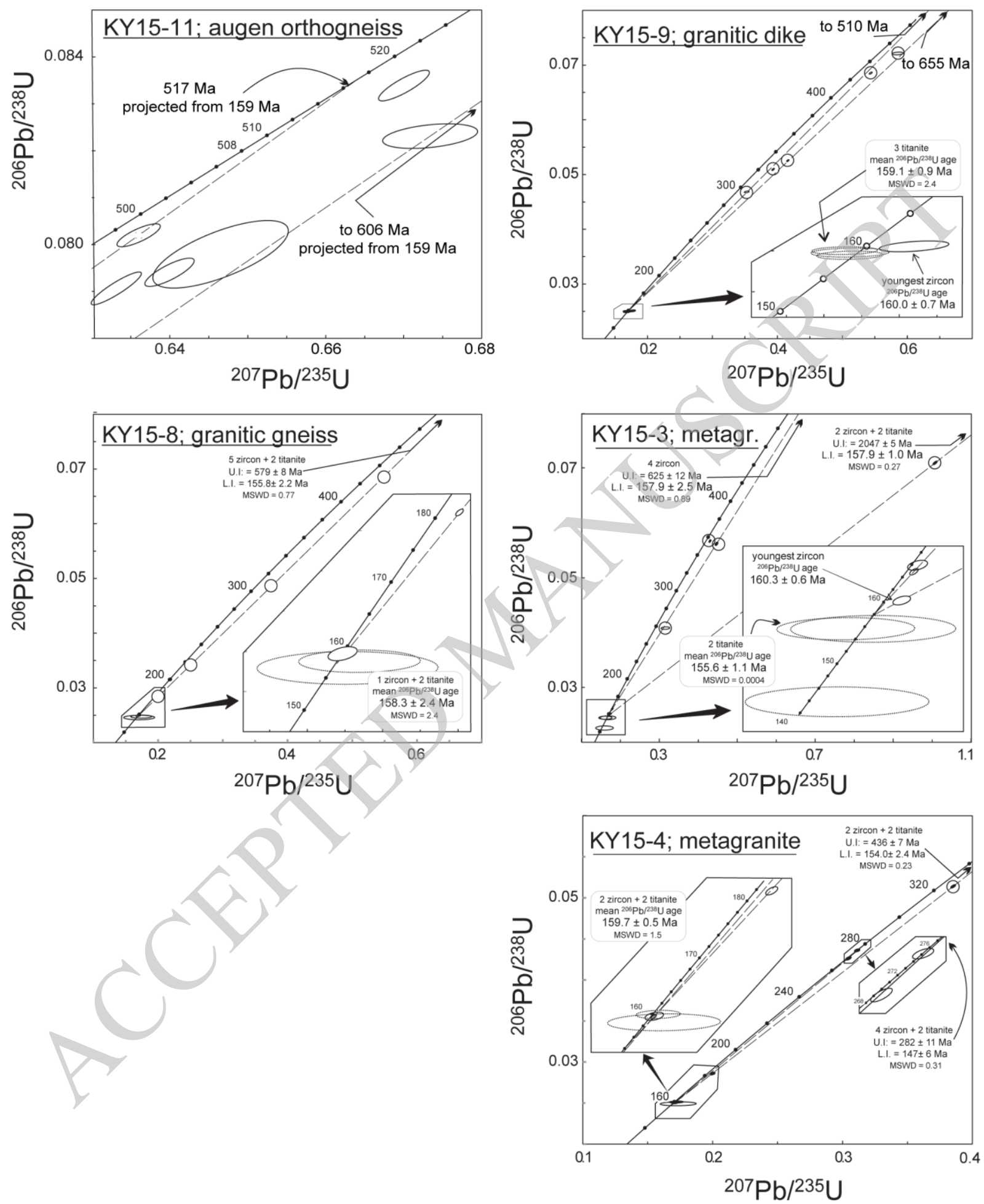
Downloaded from http://jgs.lyellcollection.org/ by guest on January 11, 2019
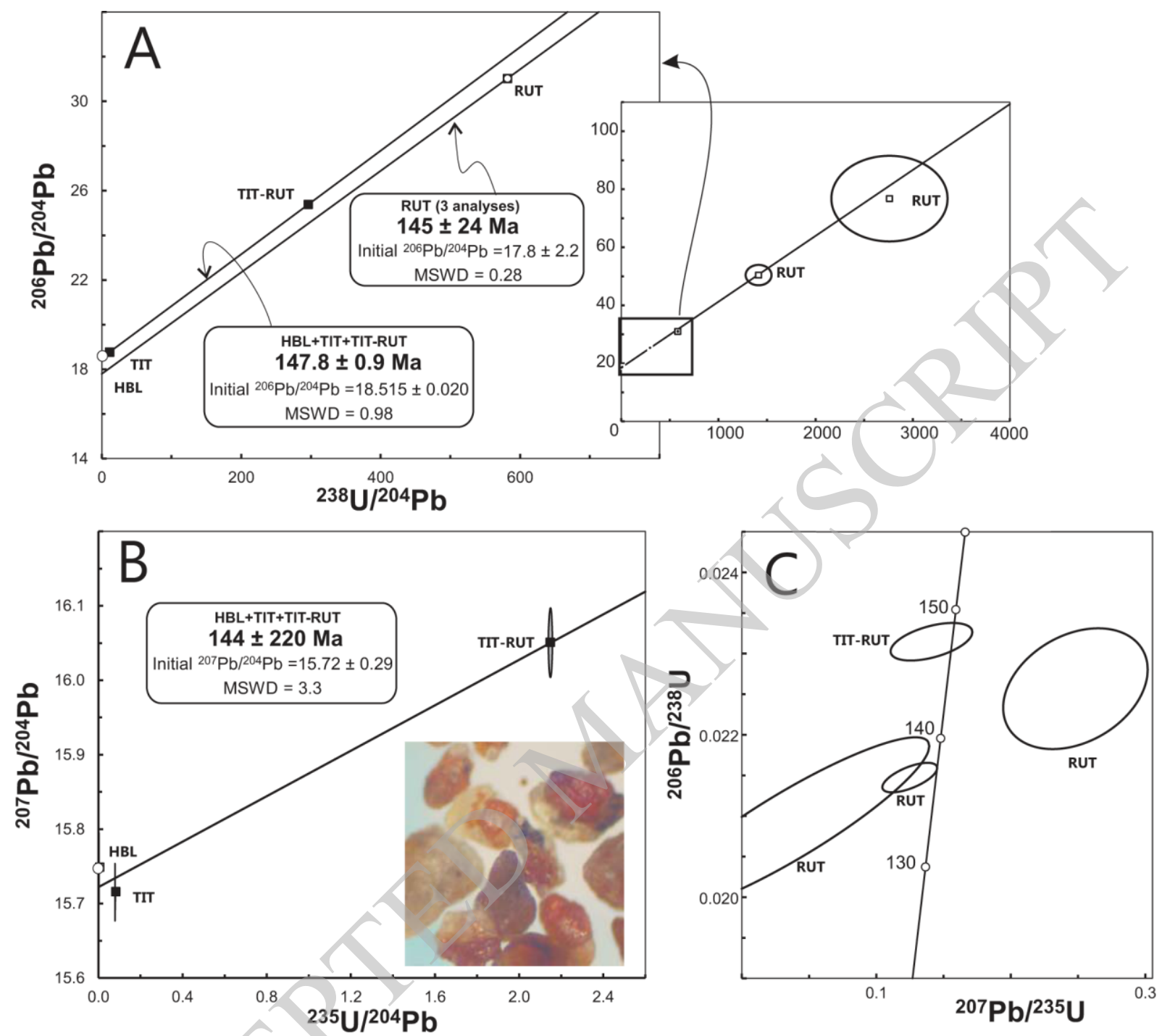


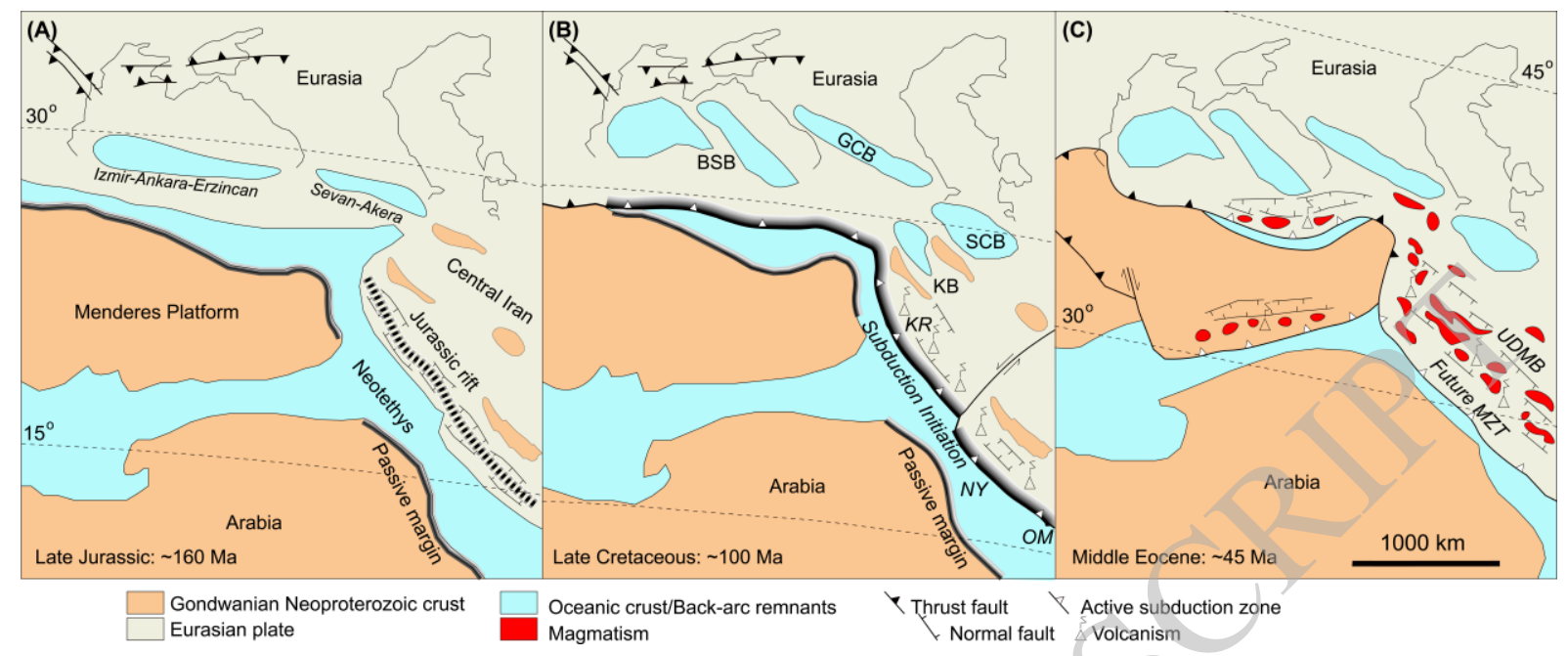




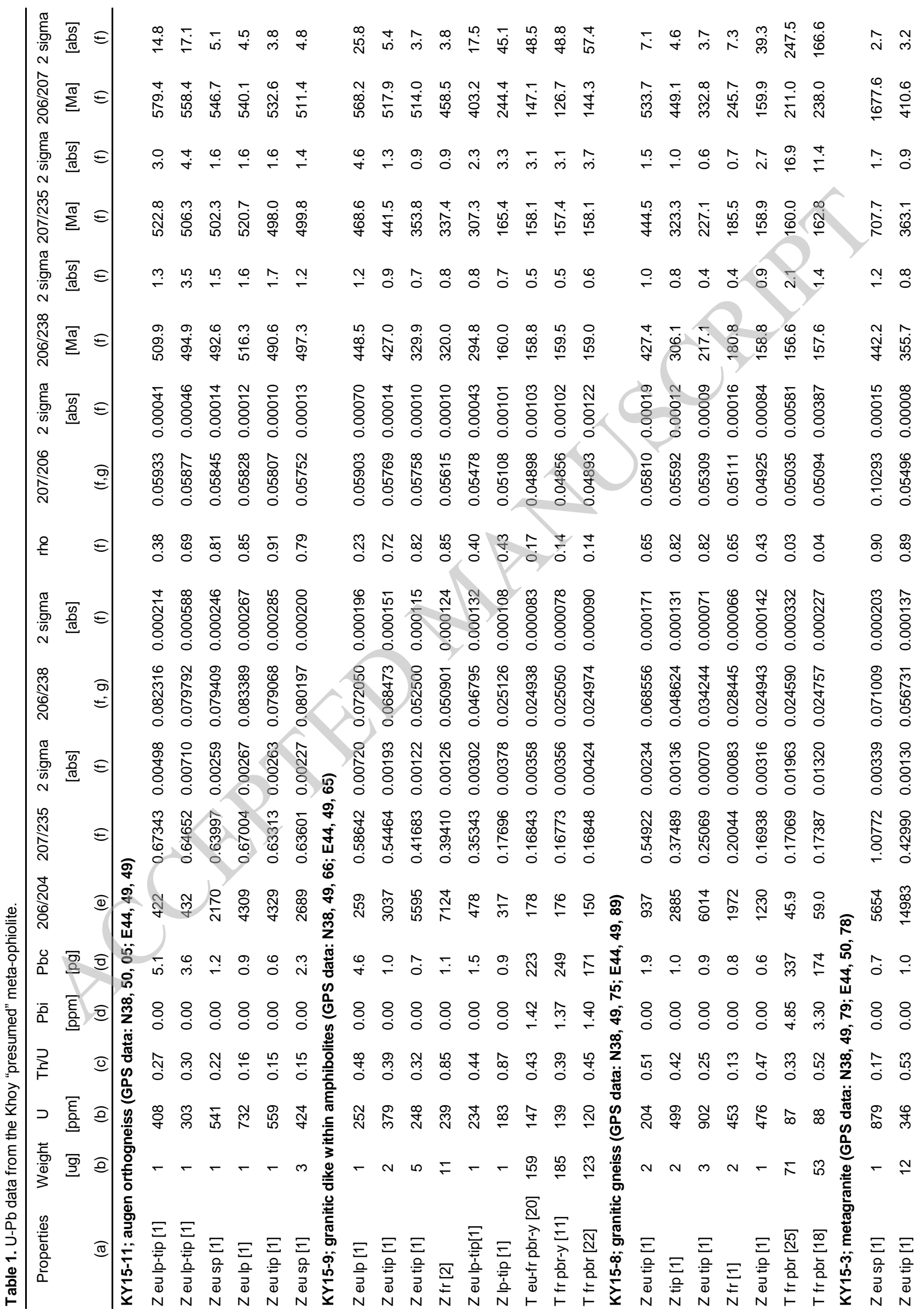




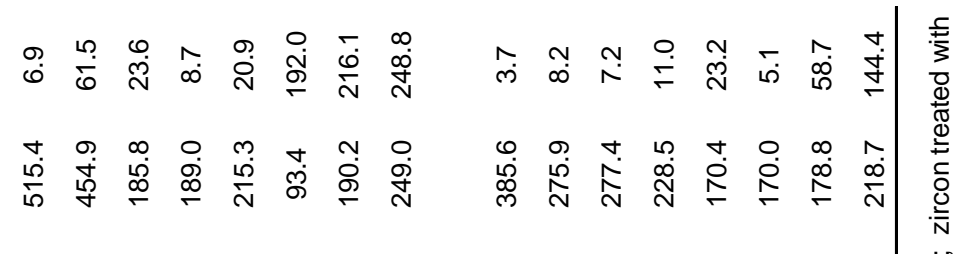

மீ)

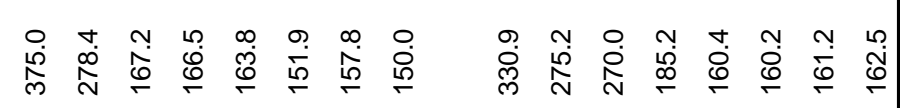

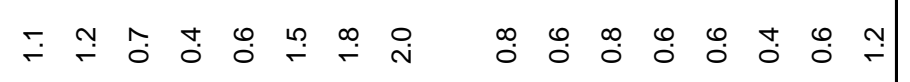

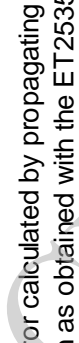

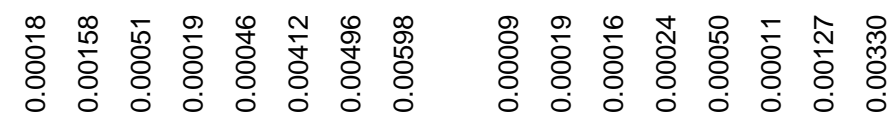

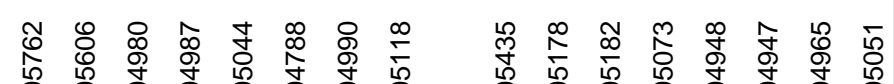

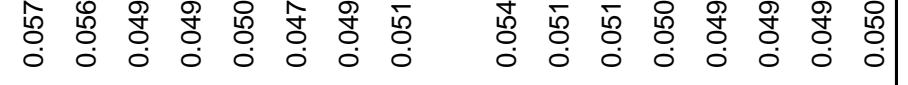

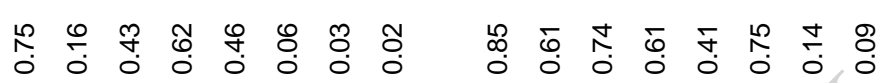

œ

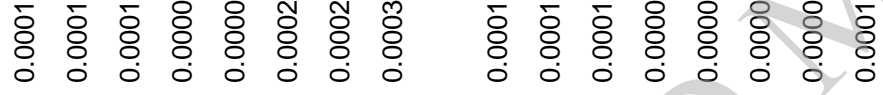

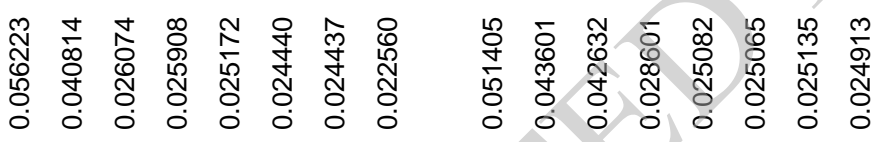

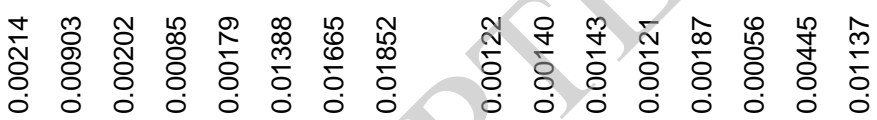

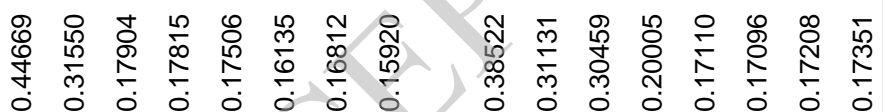

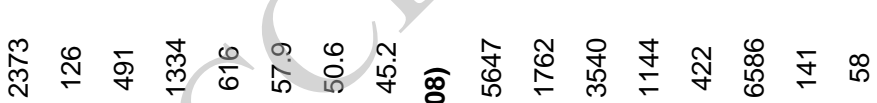

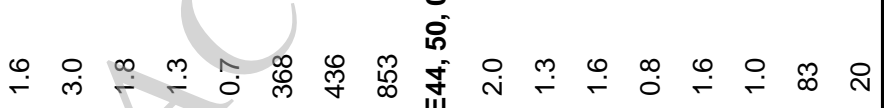

88888807808888889

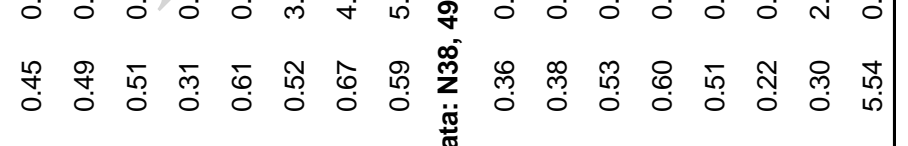

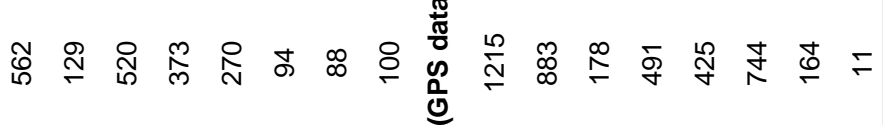

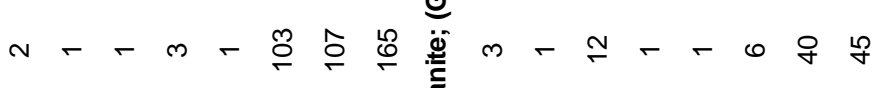

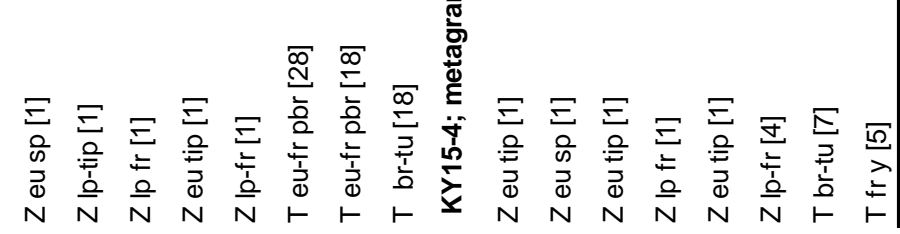




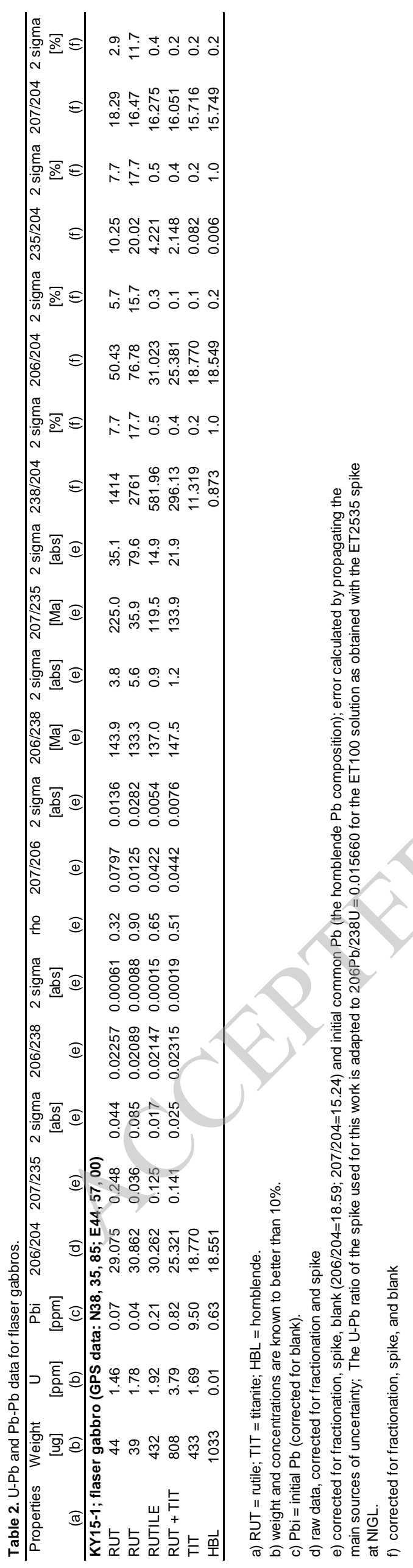

